\title{
International trade, non-tariff measures and climate change: insights from Port wine exports
}

Insights from Port wine exports

\author{
Anthony Macedo \\ Universidade de Trás-os-Montes e Alto Douro, Vila Real, Portugal \\ Sofia Gouveia and João Rebelo \\ Centre for Transdisciplinary Development Studies (CETRAD), \\ Universidade de Trás-os-Montes e Alto Douro, Vila Real, Portugal, and \\ João Santos and Helder Fraga
}

Centre for the Research and Technology of Agro-Environmental and Biological

Sciences (CITAB), Universidade de Trás-os-Montes e Alto Douro, Vila Real, Portugal

\begin{abstract}
Purpose - The purpose of this study is to investigate international trade determinants, paying special attention to variables related to climate change and non-tariff measures (NTMs), as they shape more and more world trade flows, with particular incidence on globalised goods, such as wine.

Design/methodology/approach - Based on panel data of Port wine exports to 60 countries, between 2006 and 2018, a gravity model has been estimated through Poisson pseudo-maximum likelihood. Explanatory variables include NTMs, mean temperature, temperature anomaly, gross domestic product (GDP), exchange rate, ad valorem equivalent tariffs and home bias.

Findings - The findings show that exports are inversely related to both mean temperature and temperature anomaly in importing countries. Regarding NTMs, it is found that only part of them are trade deterrent. Additionally, purchasing power in importing countries is one of the main determinants of Port wine exports. Research limitations/implications - The results show that, besides traditional economic variables, policymakers and wineries should include in their exports' decisions the impact of variables related to climate change and NTMs.

Originality/value - The novelty of this paper is to incorporate the impact of climatic variability of importing countries as a determinant of international trade of wine. Most former studies inspired of the gravity model consider explanatory variables such as GDP and exchange rate, and more recent ones started to consider NTMs too, however, this study may be the first paper to include the impact of climate change (quantified by mean temperature and temperature anomaly in importing countries) on exports.
\end{abstract}

Keywords Trade, Demand, Climate variability, Gravity model, Poisson pseudo-maximum likelihood Paper type Research paper

\section{Introduction}

At the heart of globalisation are bilateral and multilateral trade agreements, supported by the World Trade Organization (WTO) and, before 1995, by the General Agreement on Tariffs and Trade, the WTO's predecessor, which regulation seeks to ensure that trade between countries is stable and fair. However, in the present, one way of thinking about the world's trading system is as a sports match featuring a sprawling, brawling international cast of players, each with their own tactics and tricks (The Economist, 2019, p. 13).

In essence, and on the contrary to tariff measures that are easily identified, the countries usually introduce general and product-specific non-tariff measures (NTMs), which can consist

Funding: This work was supported by the project VINCI - Wine, Innovation and International Competitiveness, under the operation number SOE3/P2/F0917, FEDER - Interreg SUDOE, and national funds, through the FCT - Portuguese Foundation for Science and Technology under the projects UIDB/ SOC/04011/2020 and UIDB/04033/2020.
Received 8 April 2020 Revised 7 October 2020 Accepted 8 October 2020

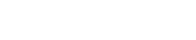


in real barriers to imports and, consequently, to the international trade. Moreover, it should be highlighted that these measures are taken in an environment of climate change [1], with a cumulative influence on production and consumption world standards. Therefore, in the analysis of export flows of a given product it is crucial to include importing countries' explanatory variables related with NTMs, as well as other variables related with climate change, in addition to the traditional explanatory variables of international trade flows included in gravity models, namely gross domestic product (GDP), population, distance and tariffs.

Typically, the influence of tariff and non-tariff measures on exports/imports is analysed using the gravity model, being wine a good reference, since it is a product with a long history of international trade, and it is a benchmarking of globalisation. For a long time, winemaking was almost exclusively a European business (Castillo et al., 2016), but recent decades brought new players with solid international trade strategies, as well as new alcohol consumption patterns across the world (Anderson et al., 2018). Likely it is that differences in the ability to preferentially lower trade barriers have played and will continue to play an important role in shaping wine trade flows (Mariani and Pomarici, 2019).

Most studies on international wine trade are based on the gravity model and consider traditional explanatory variables related to the economical masses (usually the GDP) of trading partners and geographical, cultural and commercial frictions existent between them. Only recently this type of model started to include NTMs, such as in Dal Bianco et al. (2016) and Santeramo et al. (2019), demanding the robustness of the results with new research on the field. Both studies estimate a gravity model, though they reach different results. Dal Bianco et al. (2016) found that some types of NTMs are a barrier to international trade, while Santeramo et al. (2019) found the opposite, supporting that the guarantee of entrance in domestic markets of products with higher standards indeed outweighs the extra costs faced by producers.

To improve the explanation of export and import flows, during the last two decades, several works have incorporated variables related to climate change in the analysis of international trade. An extensive stream of the literature has focussed on the effect of trade on the environment or the ecological footprint (Antweiler et al., 2001; Copeland and Taylor, 2004; Shapiro, 2016), while other studies analysed how climate can influence trade through both supply and demand sides. On the supply side, it is generally assumed that there is a threat that production costs will rise, and transport and distribution will become more vulnerable (Organisation for Economic Co-operation and Development, 2015). On the demand side, the focus is mainly on the daily impact of meteorological conditions on consumer decisions (Agnew and Thornes, 1995; Arunraj and Ahrens, 2016) and less on the long-term influence of climate change.

Regarding the wine industry, the existing research has pointed out the influence of climate and weather on quantity and quality, as well as on ageing (Ashenfelter and Storchmann, 2016), but reduced attention has been given to wine consumption. Moreover, since wine (as most alcoholic beverages) has a relatively long storability, issues related to perishable goods are not so present and the concern should not be the daily consumption, but longer periods, namely at the annual timescale, when studying international trade.

Summing up, research on the impact of climate change on international trade has been mainly focussed on the structure, behaviour and performance of the supply side, including the environmental consequences, but less on the demand side. Within demand, special attention has been paid to perishable goods with daily or short-run consumption. Therefore, a better understanding of the determinants of international trade requires additional research on the topic, namely, the influence of climate on foreign demand for non-perishable goods, such as alcoholic beverages. Within this sector, the Portuguese Port wine is a good example to be studied, since it has been present in international markets for about three centuries and $80 \%$ of the production is still exported [2] to more than 100 countries of different latitudes and 
climatic conditions. Also, on both the demand and supply sides, there is an awareness that its consumption is influenced by climatic conditions. Agnew and Thornes (1995) conclude that Port wine consumption is more frequent during the cold season, and Port wine companies are aware that climate change influences consumption patterns, warning about the need for new categories of Port wine able to respond to new consumer habits and behaviour (Hogg and Rebelo, 2018).

The main goal of this paper is to include variables related to climate change, nominated in this paper as climate variability, in the export determinants. To achieve this goal, an expanded gravity model is estimated using data from a sample of 60 countries covering the period between 2006 and 2018, using as explanatory variables of Port wine exports climate variability indicators, NTMs and control variables, such as purchasing power, tariffs, exchange rate and home bias. Besides the enrichment of the literature on the impact of NTMs (sanitary and phytosanitary (SPS) measures and technical barriers) and climate change in the international trade, the results of the study can be useful to policy decision-makers and wine firms.

The paper is structured as follows. Section 2 presents a review of the literature on the determinants of international trade, paying particular attention to NTMs and climate change/ variability. Section 3 introduces the gravity equation and the data for estimations presented and analysed in Section 4. Finally, Section 5 concludes and explores some policy and managerial implications.

\section{Literature review}

\subsection{Determinants of international trade}

The role of exports in national income is crucial and, therefore, the literature about export equations at the country level is quite extensive. Several factors were found to be trade determinants, some with a deterrent effect (trade frictions) and others with a boosting effect (trade facilitators). Bayar (2018) presents a survey of this literature and lists international trade frictions/facilitators. Foreign income (GDP is a common proxy) and population are trade facilitators in most literature and one of the most common trade frictions is the physical distance between the capitals of the countries, used to represent transportation costs. On the other hand, the existence of contiguity and trade agreements between the two trading countries is expected to enhance trade. Also, the historical relationship between countries can influence trade and can be a facilitator when it has resulted in cultural proximity, common language or important diasporas. Through basic demand laws, it is also expected a decrease in exports for a country when its real exchange rate appreciates because it increases the prices for importing countries, whereas the inverse should be expected when its real exchange rate depreciates.

Besides, studies focussing on particular sectors, as illustrated in wine trade literature (Agostino and Trivieri, 2016; Castillo et al., 2016; Dal Bianco et al., 2016; Gouveia et al., 2018; Lombardi et al., 2016; Macedo et al., 2019, 2020), account for specific variables, such as domestic supply, home bias (preference for domestic wines, usually measured through domestic wine production) and tariffs.

\subsection{International trade and NTMs}

In recent decades, policy interventions aimed to facilitate international trade through the reduction of mark-ups imposed on imported products and the introduction of measures to guarantee the safety and technical standards (Dal Bianco et al., 2016). Yet, some economic literature suggests that NTMs are used to protect domestic products (Yue et al., 2006).

In a meta-analysis, Santeramo and Lamonaca (2019) show that estimates for the effect of NTMs on agri-food trade are influenced by the type of NTM, the proxies used for NTMs, the
Insights from Port wine exports

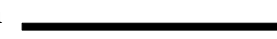


level of detail of studies, the methodology followed and study-specific assumptions. For example, de Frahan and Vancauteren (2006) argue that the harmonisation of food regulation in the European Union (EU) had a positive effect in intra-EU trade and that, despite the impact varying by sub-sector, it is verified for most sub-sectors of the food industry. On the other hand, Olper and Raimondi (2008), focussing on the trade of processed food between the United States of America (USA), Canada, Japan and EU, estimate that NTMs have a trade reduction effect. Disdier et al. (2008) find a negative impact of technical barriers to trade (TBT) and SPS measures on the trade of agricultural products as a whole. Nevertheless, they find that for some sub-sectors the effect is positive or non-significant, while it is negative for others (such as for beverages and spirits). Jayasinghe et al. (2010) studied corn seed exports from the USA and they found that SPS measures are a significant barrier to trade. They claim that too many SPS measures are imposed, but they do not support a complete removal of these measures either, as they argue that this would create negative externalities. Ferro et al. (2015) consider the effect of restrictiveness of food safety standards on exports of agricultural commodities and the results suggest that more restrictive standards increase fixed costs and, therefore, harm exports.

Regarding the effect of NTMs on the wine sector, Dal Bianco et al. (2016) find through the estimation of a gravity model that the effect of SPS measures on wine exports is negligible and that only some TBTs have a significant effect. Also estimating a gravity model, Santeramo et al. (2019) find a more positive impact of NTMs on wine imports, suggesting that SPS and export-related measures have a positive effect on imports of sparkling, bulk, and bottled wines, while TBT and pre-shipment inspection measures have a positive effect on bottled wine imports.

\subsection{International trade and climate}

The economy and the climate are intrinsically linked, both through the effect that pollution and anthropogenic greenhouse emissions produced by economic activities have on the climate in the long term and through the effect that the weather and climate have on the decisions of economic agents. If the focus is given to the effect of climate change on trade, an impact can be observed on either the supply side or the demand side.

The Organisation for Economic Co-operation and Development (2015) suggests that, on the supply side, production costs can increase because of changes observed in crop yields, fisheries catch, labour productivity and energy demand, and loss of land and capital due to sea-level rise. Additionally, supply, transport and distribution chains will be vulnerable to more frequent extreme weather events, such as severe droughts or hurricanes, being expected that these changes will have an impact on both domestic and export prices but, eventually, in the case of international trade, these effects can be more critical due to the dependence on transports.

On the demand side, as suggested by Agnew and Thornes (1995), the weather influences three consumer decisions: "when", "where" and "what" to purchase. Due to inappropriate weather conditions, a consumer may decide to prepone or postpone a specific purchase (e.g. to postpone a trip to the beach because it is raining), or he may have to change the place of purchase (e.g. to purchase in a local convenience store instead of a shopping centre because there is snow on the road). Furthermore, the shopping basket varies according to weather conditions (e.g. umbrellas are usually best sold when it rains, and ice creams when it is hot). Arunraj and Ahrens (2016) consider three more decisions that are influenced by weather: frequency, quantity and method. Undesired weather may reduce the frequency and increase online purchases, while quantity may vary according to time and frequency of purchases.

The effect of weather on businesses tends to be more discussed in the context of sensitivity analysis for retail sales (Agnew and Thornes, 1995; Stulec et al., 2019) or specific sectors, such as tourism (Wilkins et al., 2018) or finance (Floros, 2011), using daily data or surveys. 
Stulec et al. (2019) signal that in such analysis, the effect of weather is product specific, with varying weather sensitivity between months and some products being bought more impulsively than others. Therefore, they conclude that it is incorrect to infer about weather sensitivity of types of stores or groups of products.

Concerning the wine industry, on the supply side, weather conditions highly influence the quantity and quality of wine grapes, as it is common with agricultural products. But additionally, the value of some fine wines has the particularity of increasing with age, and the weather has an important impact on storability (Ashenfelter and Storchmann, 2016). The atmospheric conditions are the most important factor controlling grapevine physiological development, despite the important role also played by soils, cultural and oenological practices, all key components of the terroir. The daily progression of weather conditions governs a wide range of processes in grapevines that trigger the different phenological stages of their vegetative and reproductive cycles. Therefore, both empirical/statistical and mechanistic models have been developed to predict grapevine parameters based on weather conditions, namely for the Port wine (Costa et al., 2019; Fraga and Santos, 2017; Santos et al., 2013). On the other side, on longer timescales, the climatic characteristics of a given region also determine its viticultural suitability, preferred grapevine varieties, the wine structure, style and typicity. Hence, several agroclimatic indices applied to viticulture are commonly used for viticultural zoning under present and future climates (Santos et al., 2020). Therefore, climate change may benefit some wine regions and harm others (Ashenfelter and Storchmann, 2016; Fraga et al., 2016). For example, in northern latitudes warmer and drier growing seasons should increase the quality of the grapes, and consequently the price. That is what is concluded by Ashenfelter and Storchmann (2010a, 2010b) for the Mosel Valley region, by Ashenfelter (2010) for the Bordeaux region, and by Pan et al. (2019) for coastal California wines. However, this latter study finds that this relationship between wine prices and growing season temperatures is not linear but quadratic, so further global warming may eventually have an adverse effect. Converging with this finding, Fraga et al. (2016) project for 2041-2070 that viticulture in southern European winemaking regions will continue to be possible although with lower yields due to enhanced warming and drying conditions. Ashenfelter and Storchmann (2016) present several possible adaptations in grapevines to face climate change, but they also alert to a slow adjustment in this type of perennial crop. As suggested by Merloni et al. (2018), farmers' readiness to embrace change will be critical to face an ongoing climatic challenge.

Regarding the relationship between climate and wine demand, a gap in the literature is observed. According to the best of our knowledge, Agnew and Thornes (1995) are the only ones who have studied the weather sensitivity of wine demand. Using data from the United Kingdom they concluded that the demand for Port wine and red wine increase with cooler and wetter weather, while, high temperatures lead to an increase in the demand for white wine.

\section{Methodology and data}

\subsection{The gravity model}

Introduced by Tinbergen (1962) and named after Newton's law, the gravity model is one of the most famous models in applied international trade studies (Head and Mayer, 2014). Essentially, it explains the trade flows between two nations by the economic sizes of both (positively linked) and the distance between them (negatively linked). The economic size is generally measured by the GDP, while distance can represent the geographic term but not only, as it can be translated into different trade frictions or trade facilitators. The model was at first rejected for lack of theoretical foundations, but over the time both demand (Anderson, 1979; Anderson and Van Wincoop, 2003; Baier and Bergstrand, 2001; Bergstrand, 1985, 1990) and supply-side (Eaton and Kortum, 2002; Chaney, 2008; Helpman et al., 2008; Melitz and Ottaviano, 2008) derivations established the theoretical underpinnings [3].
Insights from Port wine exports

$\longrightarrow$


As expressed in the previous sections, besides the traditional explanatory variables, this study is particularly concerned with the effect of NTMs and climate variability on the wine industry, therefore they are included in the expanded gravity equation represented as follows:

$$
\begin{aligned}
\operatorname{exports}_{i t}= & \exp \left[\beta_{1} \ln g d p p c_{i t}+\beta_{2} \ln \text { er }_{i t}+\beta_{3} \ln \left(\text { ave }_{i t}+1\right)+\beta_{4}{\text { top } 10_{i t}}\right. \\
& +\sum_{m=1}^{M} \beta_{5 m} \ln \left(s p s_{m i t}+1\right)+\sum_{n=1}^{N} \beta_{6 n} \ln \left(t b t_{n i t}+1\right)+\beta_{7} \ln \left(\text { other }_{i t}+1\right) \\
& \left.+\beta_{8} \text { climate }_{k i t}+\varphi_{t}+\omega_{i}+u_{i t}\right]
\end{aligned}
$$

Where exports represents the annual exports (thousand euro) of Port wine to country $i$ in year $t$. As traditional explanatory variables are: $g d p p c$, the per capita GDP of country $i$; $e r$, the average annual exchange rate of country $i$ 's currency to euro; ave, the ad valorem equivalent tariffs imposed by $i$ to Port wine exports; and top10, a dummy variable equal to 1 if $i$ is a top 10 producer of wine, 0 otherwise. Regarding NTMs, sps stands for the $m$-th sub-categories of SPS measures imposed by $i$ to Port wine exports; similarly, $t b t$ stands for the $n$-th sub-categories of TBT measures; other refer to other NTMs imposed by $i$. Relatively to climate variability, climate is an indicator of actual climate conditions in country $i$, standing $k$ alternatively for i) the log-form of the mean temperature in the hottest trimester of year $t$ in country $i$ or ii) the temperature anomalies [4] based on the mean temperature in the hottest and coldest trimesters of year $t$ in country $i$. Time $\left(\varphi_{t}\right)$ and importer $\left(\omega_{i}\right)$ fixed effects [5] are included in the equation, as well as an additive statistical error $\left(u_{i t}\right)$.

As recommended by the seminal paper of Silva and Tenreyro (2006), the gravity equation will be estimated in a multiplicative form and with a non-linear estimation method, the Poisson pseudo-maximum likelihood (PPML). This approach overcomes the "zero problem" of linear methods using the logarithm of exports as a dependent variable, which happens when there is no trade between two countries and the logarithm of zero is undefined.

\subsection{Data}

Data for the exports (in euro) of Port wine were extracted from the website of Instituto de Vinhos do Douro e Porto (IVDP), the regulatory entity. The sample includes 60 importing countries [6] from 2006 to 2018 (records of earlier years are not available) and they represent $98 \%$ of the total value exported during that period.

The traditional explanatory variables were collected from different sources: per capita GDP and exchange rate (local currency unit per euro) from World Development Indicators; $a d$ valorem equivalent tariffs from Market Access Map; and ranking of top 10 wine producers from the International Organisation of Vine and Wine.

Under the Harmonised System of tariff nomenclature, Port wine exports considered in the present study are represented by the code 22042189 (before 2010, it was also included in the code 22042195), i.e. "in containers holding $<=2$ litres and of actual alcoholic strength of $>15 \%$ volume, with Protected Designation of Origin or Protected Geographical Indication". Through this code, it was possible to extract data from TRAINS and WITS online platforms for the NTMs applied to Port wine imports. There are several kinds of NTMs and they can be export- or import-related. Following UNCTAD (2019), the import-related measures (the most common ones) can be divided into technical and non-technical measures. Technical measures are constituted by SPS measures (classified under subcategory A), TBT (B), pre-shipment inspection, and other formalities (C). While there are several categories of non-technical 
measures, such as contingent trade-protective measures (D), quantity-control measures (E), price-control measures $(\mathrm{F})$, finance measure $(\mathrm{G})$, measures affecting competition $(\mathrm{H})$, traderelated investment measures (I), distribution restrictions $(\mathrm{J})$, restrictions of post-sales services $(\mathrm{K})$, subsidies and other forms of support $(\mathrm{L})$, government procurement restrictions $(\mathrm{M})$, intellectual property $(\mathrm{N})$ and rules of origin (O). Mariani and Pomarici (2019) provide a comprehensive and instructive review of NTMs applied to wine exports.

As it can be observed in Figure 1, the number of NTMs imposed by 60 of the main importers of Port wine increased significantly from 2006 to 2018. While the number of all import-related measures increased, indubitably SPS and TBT are the most common NTMs imposed to Port wine exports, which is recurrent in the wine trade. Together, they represented $86 \%$ of the NTMs both in 2006 and 2018. Therefore, special attention should be payed to the sub-categories highlighted by UNCTAD (2019) for SPS and TBT measures (Table 1). Amongst the countries imposing more TBT measures to Port wine in 2018, there was China (45 measures), Canada (27), USA (25), Australia (20) and Brazil (20). Concerning SPS measures, they were India (43), Australia (38), USA (37), Vietnam (27) and China (22).

Regarding climate variability, one of the most suitable variables to isolate its effect is the air temperature. Its averages or anomalies for the hottest and coolest trimesters (the exact months depend on the hemisphere and country) are particularly useful to emphasize the anomalous conditions of a given year (Wilks, 2020). Besides, the climate of a given region is characterized by some central tendency and variability metrics of different atmospheric variables, being air temperature one of the most important variables for this characterization (Peixoto and Oort, 1992), thus explaining its selection for the present study analysis.

Data for the computation of climate indicators were obtained from the C3S-ERA5 (Copernicus Climate Change Service-Fifth generation of ECMWF atmospheric reanalyses of the global climate) dataset, being retrieved from the Climate Data Store [7]. The ERA5 gridded data are available at a horizontal resolution of $31 \mathrm{~km}$ and this climate reanalysis data effectively incorporate observational sources in the climate model outputs. Pre-processed monthly mean 2-m air temperatures were retrieved for specific geographical sectors covering each country. Averages and anomalies of the hottest and coolest trimesters were then computed for each country. Figures 2 and 3 seem to show an inverse relationship between Port wine exports and mean temperature, both in hottest and coldest trimesters.

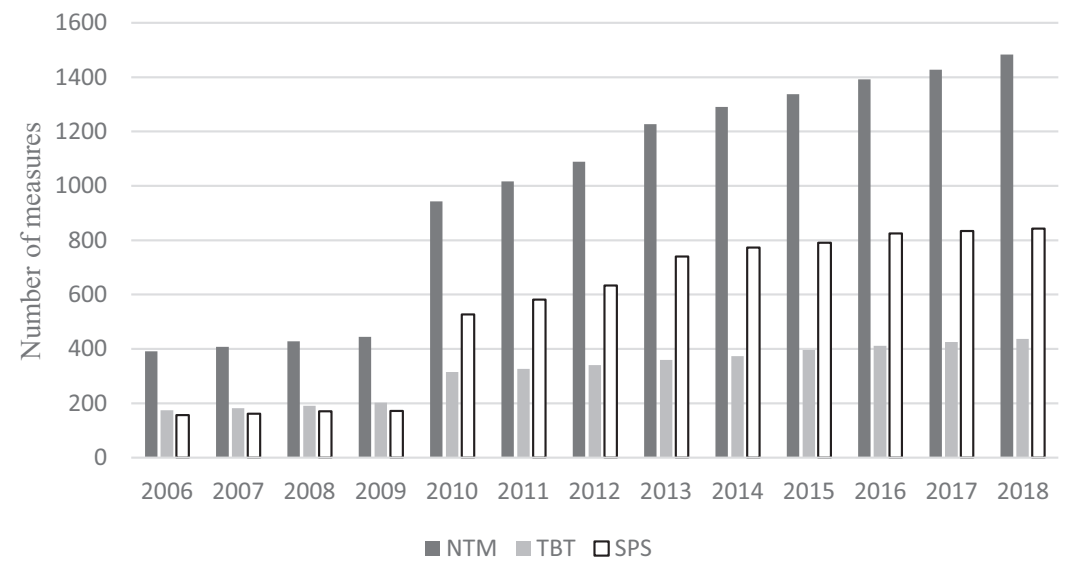

Source(s): Authors' computation based on TRAINS and WITS data for 60 countries
Insights from Port wine exports

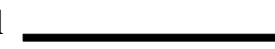


SPS sub-categories

A1 - Prohibitions/restrictions of imports for sanitary and phytosanitary reasons

A2 - Tolerance limits for residues and restricted use of substances

A3 - Labelling, marking and packaging requirements

A4 - Hygienic requirements related to sanitary and phytosanitary conditions

A5 - Treatment for elimination of plant and animal pests and disease-causing organisms in the final product or prohibition of treatment

A6 - Other requirements relating to production or postproduction processes

A8 - Conformity assessment related to sanitary and phytosanitary conditions

A9 - Sanitary and phytosanitary measures not elsewhere specified

\section{TBT sub-categories}

B1 - Import authorization/licensing related to technical barriers to trade

B2 - Tolerance limits for residues and restricted use of substances

B3 - Labelling, marking and packaging requirements

B4 - Production or post-production requirements

B6 - Product identity requirements

B7 - Product quality, safety or performance requirements

Table 1.

Sub-categories of SPS and TBT measures

B8 - Conformity assessment related to technical barriers to trade

B9 - Technical barriers to trade measures not elsewhere specified

Source(s): UNCTAD (2019)

Table 2 presents the main descriptive statistics of the variables used in the econometric models to be estimated.

\section{Results}

Table 3 presents the results estimated through PPML. Column (1) ignores the effects of NTMs and climate variability on trade. Columns (2) and (3) add two different indicators of climate variability, (2) considers the mean temperature and (3) the temperature anomalies. Column (4) does not account for the effect of climate variability but includes dummy variables for NTMs. Finally, in columns (5) and (6) both effects are estimated, and the only difference concerns the indicator of climate variability. Yearly dummy variables present jointly statistical significance in all estimations, but they are omitted due to space considerations. A heteroskedasticity-robust RESET test suggests the rejection of the null-hypothesis of misspecification in models (4) to (6), thus only the results of these estimations will be analysed in this section. Akaike's and Schwarz's Bayesian information criteria (AIC and BIC, respectively) also suggest that these models are the ones that best fit the data [8].

Estimations of models (4), (5) and (6) suggest that amongst the different sub-categories of SPS measures, only two present a deterrent effect on Port wine exports: "hygienic requirements related to sanitary and phytosanitary conditions" (A4), and "treatment for elimination of plant and animal pests and disease-causing organisms in the final product or prohibition of treatment" (A5). The former refers to hygienic practices required for food safety imposed by several importing countries. The latter refers to the obligation or prohibition of certain treatments and it is only imposed by the USA, New Zealand, Malaysia and the United Arab Emirates.

Regarding TBT measures, the coefficient for three variables (B4, B6 and B7) is negative and statistically significant. In column (4) there are "production or post-production requirements" (B4), which are requirements concerning production or post-production not classified under the SPS measures. In column (5) there are "product identity requirements" (B6), which impose conditions that need to be satisfied to identify a product with a certain denomination. In columns (5) and (6), "product quality, safety or performance requirements" 


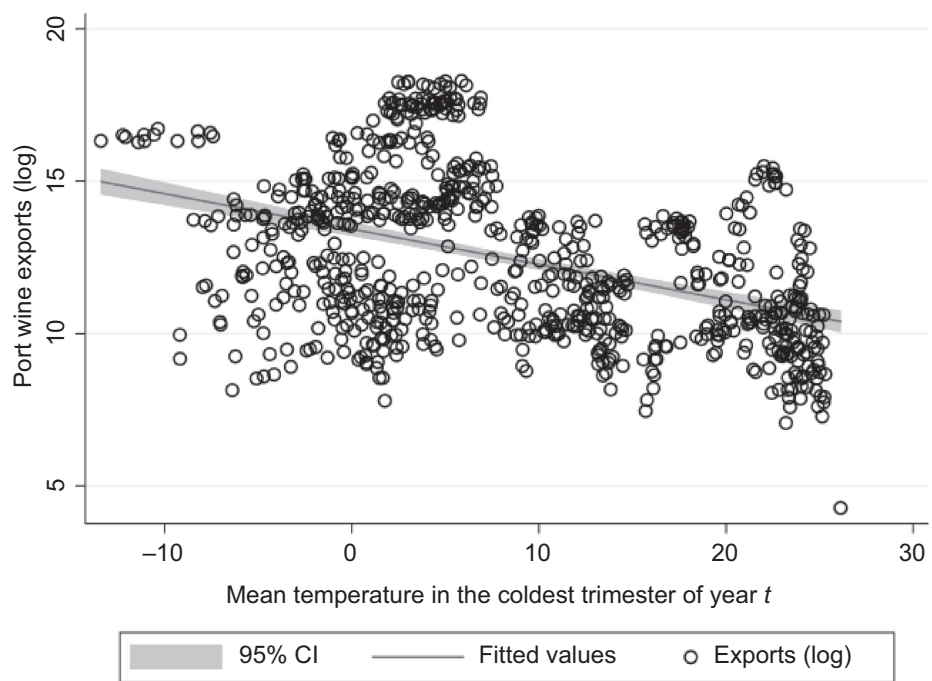

Source(s): Authors' computation based on data from IVDP and Climate Data Store for 60 countries

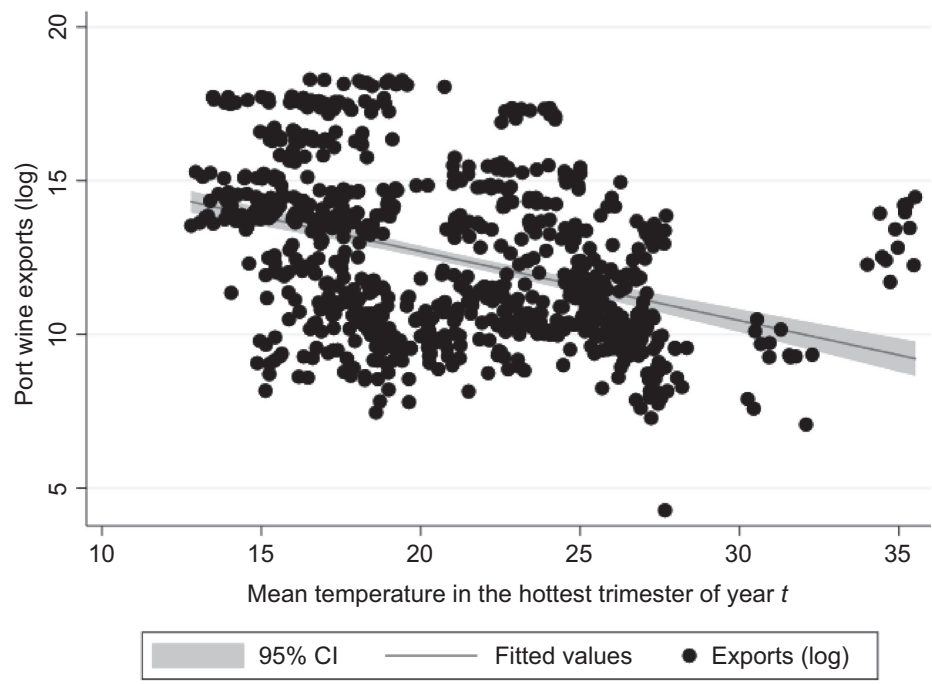

Source(s): Authors' computation based on data from IVDP and Climate Data Store for 60 countries
Insights from

Port wine exports

Figure 2.

Scatter plot of Port wine exports (log) and mean temperature $\left(\mathrm{C}^{\circ}\right)$ in the coldest trimester
Figure 3.

Scatter plot of Port wine exports $(\log )$ and mean temperature $\left(\mathrm{C}^{\circ}\right)$ in the hottest trimester

(B7) refer to the requirements of some importing countries about product quality that are not covered by other measures. Finally, the aggregation of the remaining NTMs does not present a statistically significant effect. These results suggest different effects of the various types of NTMs, which is in agreement with previous studies on the global trade of wine (Dal Bianco et al., 2016; Santeramo et al., 2019). 


\begin{tabular}{|c|c|c|c|c|c|c|}
\hline Variables & $N$ & Mean & $\mathrm{P} 50$ & SD & Min & Max \\
\hline Exports $(1000 €)$ & 777 & 5100.0 & 166.9 & 13869.6 & 0.0 & 87687.6 \\
\hline GDP per capita $(€)$ & 775 & 19917.2 & 12879.0 & 17112.8 & 814.1 & 97165.3 \\
\hline Ad valorem equivalent tariff $(\%)$ & 752 & 11.3 & 0.0 & 22.5 & 0.0 & 150.0 \\
\hline Exchange rate (LCU per $€$ ) & 780 & 664.8 & 3.8 & 3604.1 & 0.4 & 39856.6 \\
\hline Top 10 producer & 780 & 0.1 & 0.0 & & 0.0 & 1.0 \\
\hline Mean temperature & 780 & 21.2 & 21.1 & 4.7 & 12.8 & 35.5 \\
\hline Temperature anomaly (hot trimester) & 780 & 0.0 & 0.0 & 0.7 & -2.0 & 2.3 \\
\hline Temperature anomaly (cold trimester) & 780 & -0.1 & -0.1 & 1.2 & -4.2 & 3.8 \\
\hline \multicolumn{7}{|l|}{ NTMs } \\
\hline A1 & 771 & 1.1 & 1.0 & 1.1 & 0.0 & 5.0 \\
\hline $\mathrm{A} 2$ & 771 & 1.8 & 1.0 & 2.9 & 0.0 & 19.0 \\
\hline A3 & 771 & 2.3 & 2.0 & 2.6 & 0.0 & 11.0 \\
\hline A4 & 771 & 0.9 & 0.0 & 1.0 & 0.0 & 6.0 \\
\hline A5 & 771 & 0.1 & 0.0 & 0.6 & 0.0 & 5.0 \\
\hline A6 & 771 & 0.6 & 0.0 & 0.9 & 0.0 & 5.0 \\
\hline A8 & 771 & 2.6 & 2.0 & 2.5 & 0.0 & 17.0 \\
\hline A9 & 771 & 0.1 & 0.0 & 0.2 & 0.0 & 1.0 \\
\hline B1 & 771 & 0.3 & 0.0 & 0.7 & 0.0 & 4.0 \\
\hline B2 & 771 & 0.1 & 0.0 & 0.4 & 0.0 & 3.0 \\
\hline B3 & 771 & 2.9 & 3.0 & 2.7 & 0.0 & 15.0 \\
\hline B4 & 771 & 0.3 & 0.0 & 0.8 & 0.0 & 5.0 \\
\hline B6 & 771 & 0.2 & 0.0 & 0.7 & 0.0 & 3.0 \\
\hline B7 & 771 & 0.3 & 0.0 & 0.7 & 0.0 & 4.0 \\
\hline B8 & 771 & 1.1 & 0.0 & 2.5 & 0.0 & 22.0 \\
\hline B9 & 771 & 0.2 & 0.0 & 0.5 & 0.0 & 3.0 \\
\hline Others & 771 & 2.0 & 1.0 & 2.9 & 0.0 & 23.0 \\
\hline
\end{tabular}

Note(s): $N=$ number of observations; $\mathrm{P} 50=$ median; $\mathrm{SD}=$ standard deviation; Min $=$ minimum value; Max = maximum value; For the binary variables the mean represents the percentage of observations equal

Table 2. to one

Source(s): Authors' computation

Regarding the climate change variables, it is estimated that the mean temperature in the hottest trimester and the temperature anomaly in the hottest trimester in importing countries have a statistically significant coefficient with a negative sign. An increase of $1 \%$ in mean temperatures of the hottest trimester of country $i$ decrease exports of Port wine to that country by $0.51 \%$, ceteris paribus. For example, in a country where the mean temperature in the hottest trimester is $21^{\circ} \mathrm{C}$ (mean of the sample), it is expected that an increase to $22^{\circ} \mathrm{C}$ would generate a decrease of $2.43 \%(\simeq(22-21) / 21 * 0.0051)$ in Port wine exports to that country. While an increase of $1^{\circ} \mathrm{C}$ in temperature anomaly of the hottest trimester would decrease exports by $3.54 \%(\simeq \exp (-0.036)-1)$. On the other hand, the temperature anomaly in the coldest trimester has not a statistically significant effect (despite the coefficient being negative too). These results suggest that climate has some effect on the wine trade and that global warming may become a concern for Port wine producers.

Concerning the control variables, the per capita GDP is statistically significant, and the coefficients are nearly the same in columns (4)-(6). On average, a 1\% variation in per capita GDP of a country $i$ generates a variation in the same direction of roughly $1.55 \%$ in Port wine exports to that country, ceteris paribus. As suggested by the literature, this result highlights the important role of purchasing power for wine trade in general (Castillo et al., 2016; Dal Bianco et al., 2016) and Port wine in particular (Gouveia et al., 2018; Macedo et al., 2020).

The variable exchange rate does not present a statically significant effect on Port wine exports, which indicates that euro appreciation and/or depreciation do not significantly affect 


\begin{tabular}{|c|c|c|c|c|c|c|c|}
\hline Variables & (1) & (2) & (3) & (4) & (5) & (6) & Insights from \\
\hline GDPpc & $\begin{array}{l}1.813^{* *} \\
(0.623)\end{array}$ & $\begin{array}{l}1.762 * * \\
(0.616)\end{array}$ & $\begin{array}{l}1.753 * * \\
(0.618)\end{array}$ & $\begin{array}{l}1.581^{*} \\
(0.640)\end{array}$ & $\begin{array}{l}1.558^{*} \\
(0.643)\end{array}$ & $\begin{array}{l}1.533^{*} \\
(0.639)\end{array}$ & exports \\
\hline Exc. rate & $\begin{array}{c}-0.291 \\
(0.199)\end{array}$ & $\begin{array}{c}-0.300 \\
(0.187)\end{array}$ & $\begin{array}{c}-0.302 \\
(0.189)\end{array}$ & $\begin{array}{r}-0.101 \\
(0.092)\end{array}$ & $\begin{array}{c}-0.117 \\
(0.088)\end{array}$ & $\begin{array}{r}-0.142 \\
(0.097)\end{array}$ & \\
\hline Tariffs & $\begin{array}{l}0.069 \\
(0.076)\end{array}$ & $\begin{array}{c}0.075 \\
(0.075)\end{array}$ & $\begin{array}{c}0.076 \\
(0.075)\end{array}$ & $\begin{array}{c}0.016 \\
(0.022)\end{array}$ & $\begin{array}{c}0.010 \\
(0.024)\end{array}$ & $\begin{array}{c}0.004 \\
(0.026)\end{array}$ & \\
\hline Top10 & $\begin{array}{r}-0.072 \\
(0.063)\end{array}$ & $\begin{array}{c}-0.051 \\
(0.056)\end{array}$ & $\begin{array}{r}-0.048 \\
(0.056)\end{array}$ & $\begin{array}{r}-0.046 \\
(0.047)\end{array}$ & $\begin{array}{r}-0.033 \\
(0.043)\end{array}$ & $\begin{array}{r}-0.027 \\
(0.043)\end{array}$ & \\
\hline Mean temp & & $\begin{array}{c}-0.550 * * \\
(0.187)\end{array}$ & & & $\begin{array}{c}-0.512^{* *} \\
(0.164)\end{array}$ & & \\
\hline Anomaly (hot) & & & $\begin{array}{c}-0.032 * * \\
(0.012)\end{array}$ & & & $\begin{array}{c}-0.036^{* *} \\
(0.013)\end{array}$ & \\
\hline Anomaly (cold) & & & $\begin{array}{c}-0.001 \\
(0.009)\end{array}$ & & & $\begin{array}{c}-0.012 \\
(0.009)\end{array}$ & \\
\hline $\mathrm{A} 1$ & & & & $\begin{array}{r}-0.013 \\
(0.042)\end{array}$ & $\begin{array}{c}-0.013 \\
(0.045)\end{array}$ & $\begin{array}{r}-0.026 \\
(0.048)\end{array}$ & \\
\hline A2 & & & & $\begin{array}{c}0.019 \\
(0.040)\end{array}$ & $\begin{array}{c}0.030 \\
(0.030)\end{array}$ & $\begin{array}{c}0.035 \\
(0.031)\end{array}$ & \\
\hline A3 & & & & $\begin{array}{c}-0.036 \\
(0.034)\end{array}$ & $\begin{array}{c}-0.029 \\
(0.036)\end{array}$ & $\begin{array}{c}-0.028 \\
(0.036)\end{array}$ & \\
\hline A4 & & & & $\begin{array}{c}-0.261 * * \\
(0.080)\end{array}$ & $\begin{array}{c}-0.283 * * \\
(0.083)\end{array}$ & $\begin{array}{c}-0.295 * * \\
(0.085)\end{array}$ & \\
\hline A5 & & & & $\begin{array}{l}-0.052^{* * *} \\
(0.011)\end{array}$ & $\begin{array}{l}-0.054^{* *} \\
(0.010)\end{array}$ & $\begin{array}{l}-0.057^{* *} \\
(0.011)\end{array}$ & \\
\hline A6 & & & & $\begin{array}{l}0.316 \\
(0.171)\end{array}$ & $\begin{array}{l}0.229 \\
(0.146)\end{array}$ & $\begin{array}{l}0.218 \\
(0.154)\end{array}$ & \\
\hline A8 & & & & $\begin{array}{l}0.018 \\
(0.053)\end{array}$ & $\begin{array}{c}0.026 \\
(0.051)\end{array}$ & $\begin{array}{l}0.035 \\
(0.052)\end{array}$ & \\
\hline A9 & & & & $\begin{array}{r}-0.058 \\
(0.172)\end{array}$ & $\begin{array}{c}0.014 \\
(0.170)\end{array}$ & $\begin{array}{l}0.056 \\
(0.176)\end{array}$ & \\
\hline B1 & & & & $\begin{array}{r}-0.137 \\
(0.113)\end{array}$ & $\begin{array}{r}-0.133 \\
(0.110)\end{array}$ & $\begin{array}{c}-0.151 \\
(0.106)\end{array}$ & \\
\hline B2 & & & & $\begin{array}{r}-0.087 \\
(0.050)\end{array}$ & $\begin{array}{c}-0.081 \\
(0.051)\end{array}$ & $\begin{array}{r}-0.088 \\
(0.054)\end{array}$ & \\
\hline B3 & & & & $\begin{array}{l}0.044 \\
(0.042)\end{array}$ & $\begin{array}{c}0.052 \\
(0.045)\end{array}$ & $\begin{array}{c}0.052 \\
(0.047)\end{array}$ & \\
\hline B4 & & & & $\begin{array}{c}-0.097^{*} \\
(0.048)\end{array}$ & $\begin{array}{r}-0.084 \\
(0.049)\end{array}$ & $\begin{array}{r}-0.086 \\
(0.050)\end{array}$ & \\
\hline B6 & & & & $\begin{array}{r}-0.162 \\
(0.093)\end{array}$ & $\begin{array}{r}-0.191^{*} \\
(0.096)\end{array}$ & $\begin{array}{r}-0.223 \\
(0.114)\end{array}$ & \\
\hline B7 & & & & $\begin{array}{c}-0.112 \\
(0.060)\end{array}$ & $\begin{array}{c}-0.129 * \\
(0.063)\end{array}$ & $\begin{array}{c}-0.150^{*} \\
(0.071)\end{array}$ & \\
\hline B8 & & & & $\begin{array}{l}0.057 \\
(0.033)\end{array}$ & $\begin{array}{c}0.046 \\
(0.036)\end{array}$ & $\begin{array}{l}0.054 \\
(0.036)\end{array}$ & $\begin{array}{r}\text { Table } 3 . \\
\text { Results of the }\end{array}$ \\
\hline B9 & & & & $\begin{array}{r}-0.300 \\
(0.185)\end{array}$ & $\begin{array}{c}-0.322 \\
(0.178)\end{array}$ & $\begin{array}{c}-0.332 \\
(0.175)\end{array}$ & $\begin{array}{l}\text { estimations of the } \\
\text { PPML model for }\end{array}$ \\
\hline & & & & & & (continued) & $\begin{array}{l}\text { exports of Port wine in } \\
\text { thousand euro }\end{array}$ \\
\hline
\end{tabular}




\begin{tabular}{|c|c|c|c|c|c|c|c|}
\hline \multirow[t]{5}{*}{ JES } & Variables & (1) & (2) & (3) & (4) & (5) & (6) \\
\hline & \multicolumn{4}{|l|}{ Other NTMs } & $\begin{array}{c}0.021 \\
(0.023)\end{array}$ & $\begin{array}{c}0.024 \\
(0.023)\end{array}$ & $\begin{array}{c}0.025 \\
(0.023)\end{array}$ \\
\hline & Observations & 735 & 735 & 735 & 735 & 735 & 735 \\
\hline & Time effects' significance & $\begin{array}{c}332.97 * * \\
{[0.000]}\end{array}$ & $\begin{array}{c}509.43^{* *} \\
{[0.000]}\end{array}$ & $\begin{array}{c}476.98 * * \\
{[0.000]}\end{array}$ & $\begin{array}{c}135.79 * * \\
{[0.000]}\end{array}$ & $\begin{array}{c}102.76^{* * *} \\
{[0.000]}\end{array}$ & $\begin{array}{l}75.92 * * \\
{[0.000]}\end{array}$ \\
\hline & RESET & $\begin{array}{c}2.13 \\
{[0.145]}\end{array}$ & $\begin{array}{l}2.40 \\
{[0.121]}\end{array}$ & $\begin{array}{l}1.85 \\
{[0.173]}\end{array}$ & $\begin{array}{l}11.12^{* * *} \\
{[0.001]}\end{array}$ & $\begin{array}{l}10.84^{* * *} \\
{[0.001]}\end{array}$ & $\begin{array}{c}9.38 * * \\
{[0.002]}\end{array}$ \\
\hline & AIC & 73714.95 & 72648.11 & 72580.92 & 57300.74 & 56479.94 & 56028.71 \\
\hline & $B I C$ & 73792.07 & 72730.06 & 72667.68 & 57452.54 & 56636.33 & 56189.70 \\
\hline
\end{tabular}

Note(s): Robust standard errors in parentheses; $*^{*} p<0.05,{ }^{*} p<0.1$; Figures in [ ] indicate $p$-values; Time dummies included but not reported

Table 3.

Source(s): Authors' computation

Port wine exports, a finding that is consistent with previous studies (Gouveia et al., 2018). Moreover, advalorem equivalent tariffs do not present a statistically significant effect on Port wine exports. The lack of significance for tariffs is particularly interesting and was already pointed by Gouveia et al. (2018) and Macedo et al. (2020), suggesting that tariffs have not a deterrent effect on the wine trade. At least two explanations are possible for this. The first is that tariffs remained relatively stable during the period of study, so tariffs in the main destination countries did not vary significantly to provoke any effect on trade (remember the model includes countries fixed effect). The second is that Port wine is a product so much differentiated that it can surmount custom costs, i.e. importing countries do not find a reliable substitute so they must import Port wine. Additionally, no home bias effect was estimated, so a country being a top 10 wine producer will not affect the exports of Port wine. The wine trade literature has usually concluded that home bias induces trade resistance (Dal Bianco et al., 2016; Macedo et al., 2020), but this result is different, suggesting a highly specific nature of Port wine compared with wine in general.

\section{Discussion and final remarks}

The results of this study suggest that per capita wealth of destination countries has a positive effect on the exports of Port wine. Since Port wine is more consumed in countries with high per capita income and it is positioned as a luxury good (with an income elasticity greater than one), the stakeholders of the industry should pay special attention to these markets.

The previous positive effect is mitigated by the negative influence of climate change. The results show that Port wine exports are negatively affected by the mean temperature in the hottest trimester and by the temperature anomaly in the hottest trimester of the importing country, reporting that there is an inverse relationship between Port wine consumption and temperature in importing countries.

Exchange rates, tariffs and the destination country being a top wine producer do not seem to be significant determinants of Port wine exports. The result for tariffs contrasts with the negative and statistically significant impact of this variable for the wine sector in general (Dal Bianco et al., 2016), which may be explained by the specific and singular nature of Port wine (a fortified wine) and its long presence in international markets. Also, the results identify which SPS and TBT measures can adversely affect Port wine exports. These results provide useful information for policymakers who are interested in the effect of country-specific NTMs on competitiveness, helping them to obtain insights for negotiating trade agreements.

Overall, this study provides policy and managerial lessons. The fact that most NTMs do not have a statistically significant effect excludes the possibility that they were introduced to protect domestic products. However, the argument that they were introduced to promote 
trade cannot be proven either, especially since certain measures have the opposite effect. Then, the Port wine industry should be concerned not only with the already well-studied impact of climate change on vineyards but also with its likely long-term implications on consumption habits. Solutions must be sought to adapt Port wine consumption to warmer climates, for example through cocktails, reinforcing the policy and entrepreneurial measures related to innovation, rejuvenation and image of Port wine as proposed by Hogg and Rebelo (2018), and marketing strategies more focussed on autumn and winter consumption.

This study is not exempt from limitations, starting with the constraints in terms of data availability, which with a longer period of study would probably allow verifying more severe changes in mean temperatures. Besides, the conclusions of this paper are based on fortified wine, so they are not necessarily transposable to still wines. Therefore, it would be interesting for wine economics literature to compare the results of this study with future similar analyses to still wines, maybe distinguishing red and white wines. Moreover, econometric models can also be fed by climate change projections for the upcoming decades, generated by state-of-theart climate models driven by different anthropogenic greenhouse gas emission pathways. This approach will allow the production of future scenarios of wine trade that may represent an important decision support tool for the winemaking sector.

\section{Notes}

1. There is a distinction to be made between "climate change" and "climate variability". While the former is more adequate for long-term analysis, the latter is indicated for year to year analysis (as it will be the case in this study).

2. Additionally, between the main fortified wines (Port, Sherry, Marsala, Madeira and Samos), Port wine, with an alcoholic content between 16.5 and $22 \%$ volume, has a market dominant position. In 2018 it had a market share of $71 \%$ of this typology of wine (Rebelo et al., 2020).

3. See Head and Mayer (2014) for a detailed literature review regarding the evolution of the gravity equation.

4. Following the Glossary of Meteorology of the American Meteorological Society (http://glossary. ametsoc.org/wiki/Anomaly), the temperature anomaly in country $i$ is computed as the deviation of temperature over a period of time (in this paper, the hottest or the coldest trimesters) from the average temperature observed over the full time period (baseline long-term mean).

5. Although the fixed effects allow to control unobserved heterogeneity constant over time, they do not allow to include time-invariant variables (e.g.: culture, religion and law).

6. Antigua and Barbuda, Argentina, Australia, Austria, Belgium, Brazil, Bulgaria, Canada, Cape Verde, Chile, China, Colombia, Costa Rica, Croatia, Cuba, Cyprus, Czech Republic, Denmark, Estonia, Finland, France, Germany, Greece, Guatemala, Hong Kong, Hungary, India, Ireland, Israel, Italy, Japan, Kazakhstan, Latvia, Lithuania, Luxembourg, Malaysia, Malta, Mexico, Morocco, Netherlands, New Zealand, Panama, Paraguay, Peru, Philippines, Poland, Romania, Russia, Slovakia, Slovenia, Spain, Sweden, Switzerland, Turkey, United Arab Emirates, United Kingdom, USA, Uruguay, Venezuela and Vietnam.

7. https://cds.climate.copernicus.eu/cdsapp\#!/home.

8. To check the robustness of the results, two additional regressions were estimated. The first regression excluding countries where the predominant religion imposes limits to alcohol consumption, such as UAE, Kazakhstan, Morocco, Malaysia, Turkey and India. The second regression using a continuous variable for wine production in the importing country instead of the top-10 producer dummy variable. Both regression estimations provide similar results to the ones presented in Table 3. These results are available upon request to the authors.

\section{References}

Agnew, M.D. and Thornes, J.E. (1995), "The weather sensitivity of the UK food retail and distribution industry", Meteorological Applications, Vol. 2 No. 2, pp. 137-147. 
Agostino, M. and Trivieri, F. (2016), "European wines exports towards emerging markets. The role of geographical identity", Journal of Industry, Competition and Trade, Vol. 16 No. 2, pp. 233-256.

Anderson, J.E. and Van Wincoop, E. (2003), "Gravity with gravitas: a solution to the border puzzle", American Economic Review, Vol. 93 No. 1, pp. 170-192.

Anderson, K., Meloni, G. and Swinnen, J. (2018), "Global alcohol markets: evolving consumption patterns, regulations, and industrial organizations", Annual Review of Resource Economics, Vol. 10 No. 1, pp. 105-132.

Anderson, J.E. (1979), "A theoretical foundation for the gravity equation”, American Economic Review, Vol. 69 No. 1, pp. 106-116.

Antweiler, W., Copeland, B.R. and Taylor, M.S. (2001), "Is free trade good for the environment?", American Economic Review, Vol. 91 No. 4, pp. 877-908.

Arunraj, N.S. and Ahrens, D. (2016), "Estimation of non-catastrophic weather impacts for retail industry", International Journal of Retail and Distribution Management, Vol. 44 No. 7, pp. 731-753.

Ashenfelter, O. and Storchmann, K. (2010a), "Measuring the economic effect of global warming on viticulture using auction, retail, and wholesale prices", Review of Industrial Organization, Vol. 37 No. 1, pp. 51-64.

Ashenfelter, O. and Storchmann, K. (2010b), "Using hedonic models of solar radiation and weather to assess the economic effect of climate change: the case of mosel valley vineyards", Review of Economics and Statistics, Vol. 92 No. 2, pp. 333-349.

Ashenfelter, O. and Storchmann, K. (2016), "Climate change and wine: a review of the economic implications", Journal of Wine Economics, Vol. 11 No. 1, pp. 105-138.

Ashenfelter, O. (2010), "Predicting the quality and prices of Bordeaux wine", Journal of Wine Economics, Vol. 5 No. 1, pp. 40-52.

Baier, S.L. and Bergstrand, J.H. (2001), "The growth of world trade: tariffs, transport costs, and income similarity", Journal of International Economics, Vol. 53 No. 1, pp. 1-27.

Bayar, G. (2018), "Estimating export equations: a survey of the literature”, Empirical Economics, Vol. 54 No. 2, pp. 629-672.

Bergstrand, J.H. (1985), "The gravity equation in international trade: some microeconomic foundations and empirical evidence", The Review of Economics and Statistics, Vol. 67 No. 3, pp. 474-481.

Bergstrand, J.H. (1990), "The Heckscher-Ohlin-Samuelson model, the Linder hypothesis and the determinants of bilateral intra-industry trade", The Economic Journal, Vol. 100 No. 403, pp. 1216-1229.

Castillo, J.S., Villanueva, E.C. and García-Cortijo, M.C. (2016), "The international wine trade and its new export dynamics (1988-2012): a gravity model approach”, Agribusiness, Vol. 32 No. 4, pp. 466-481.

Chaney, T. (2008), "Distorted gravity: the intensive and extensive margins of international trade", American Economic Review, Vol. 98 No. 4, pp. 1707-1721.

Copeland, B.R. and Taylor, M.S. (2004), "Trade, growth, and the environment", Journal of Economic Literature, Vol. 42 No. 1, pp. 7-71.

Costa, R., Fraga, H., Fonseca, A., de Cortázar-Atauri, I.G., Val, M.C., Carlos, C., Reis, S. and Santos, J.A. (2019), "Grapevine phenology of cv. Touriga Franca and Touriga Nacional in the Douro wine region: modelling and climate change projections", Agronomy, Vol. 9 No. 4.

Dal Bianco, A., Boatto, V.L., Caracciolo, F. and Santeramo, F.G. (2016), "Tariffs and non-tariff frictions in the world wine trade", European Review of Agricultural Economics, Vol. 43 No. 1, pp. 31-57.

de Frahan, B.H. and Vancauteren, M. (2006), "Harmonisation of food regulations and trade in the Single Market: evidence from disaggregated data", European Review of Agricultural Economics, Vol. 33 No. 3, pp. 337-360. 
Disdier, A.-C., Fontagné, L. and Mimouni, M. (2008), "The impact of regulations on agricultural trade: evidence from the SPS and TBT agreements", American Journal of Agricultural Economics, Vol. 90 No. 2, pp. 336-350.

Eaton, J. and Kortum, S. (2002), “Technology, geography, and trade”, Econometrica, Vol. 70 No. 5, pp. 1741-1779.

Ferro, E., Otsuki, T. and Wilson, J.S. (2015), "The effect of product standards on agricultural exports", Food Policy, Vol. 50, pp. 68-79.

Floros, C. (2011), "On the relationship between weather and stock market returns", Studies in Economics and Finance, Vol. 28 No. 1, pp. 5-13.

Fraga, H. and Santos, J.A. (2017), "Daily prediction of seasonal grapevine production in the Douro wine region based on favourable meteorological conditions", Australian Journal of Grape and Wine Research, Vol. 23 No. 2, pp. 296-304.

Fraga, H., de Cortázar-Atauri, I.G., Malheiro, A.C. and Santos, J.A. (2016), "Modelling climate change impacts on viticultural yield, phenology and stress conditions in Europe", Global Change Biology, Vol. 22 No. 11, pp. 3774-3788.

Gouveia, S., Rebelo, J. and Lourenço-Gomes, L. (2018), "Port wine exports: a gravity model approach", International Journal of Wine Business Research, Vol. 30 No. 2, pp. 218-242.

Head, K. and Mayer, T. (2014), "Gravity equations: workhorse, toolkit, and cookbook", in Gopinath, G., Helpman, E. and Rogoff, K. (Eds), Handbook of International Economics, Elsevier, Vol. 4, pp. 131-195.

Helpman, E., Melitz, M. and Rubinstein, Y. (2008), "Estimating trade flows: trading partners and trading volumes", The Quarterly Journal of Economics, Vol. 123 No. 2, pp. 441-487.

Hogg, T. and Rebelo, J. (2018), Rumo estratégico para o setor dos vinhos do Porto e Douro - Síntese, Porto, available at: http://www.ivdp.pt/pt/docs/SìNTESE.pdf (accessed 2 March 2020).

Jayasinghe, S., Beghin, J.C. and Moschini, G. (2010), "Determinants of world demand for US corn seeds: the role of trade costs", American Journal of Agricultural Economics, Vol. 92 No. 4, pp. 999-1010.

Lombardi, P., Dal Bianco, A., Freda, R., Caracciolo, F. and Cembalo, L. (2016), "Development and trade competitiveness of the European wine sector: a gravity analysis of intra-EU flows", Wine Economics and Policy, Vol. 5 No. 1, pp. 50-59.

Macedo, A., Gouveia, S. and Rebelo, J. (2019), "Does wine quality have a bearing on exports?", Agris on-line Papers in Economics and Informatics, Vol. 11 No. 4, pp. 49-59.

Macedo, A., Gouveia, S. and Rebelo, J. (2020), "Horizontal differentiation and determinants of wine exports: evidence from Portugal”, Journal of Wine Economics, Vol. 12 No. 2, pp. 163-180.

Mariani, A. and Pomarici, E. (2019), "Barriers to wine trade", in Ugaglia, A., Cardebat, J.-M. and Corsi, A. (Eds), The Palgrave Handbook of Wine Industry Economics, Palgrave Macmillan, pp. 291-315.

Melitz, M.J. and Ottaviano, G.I.P. (2008), "Market size, trade, and productivity", The Review of Economic Studies, Vol. 75 No. 1, pp. 295-316.

Merloni, E., Camanzi, L., Mulazzani, L. and Malorgio, G. (2018), "Adaptive capacity to climate change in the wine industry: a Bayesian network approach", Wine Economics and Policy, Vol. 7 No. 2, pp. 165-177.

Olper, A. and Raimondi, V. (2008), "Explaining national border effects in the QUAD food trade", Journal of Agricultural Economics, Vol. 59 No. 3, pp. 436-462.

Organisation for Economic Co-operation and Development (2015), The Economic Consequences of Climate Change, OECD Publishing, Paris.

Pan, Q., Sumner, D. and Lapsley, J. (2019), "Impacts of climate change on retail prices of coastal California wines", 2019 Agricultural and Applied Economics Association Annual Meeting, Atlanta, GA, available at: https://ageconsearch.umn.edu/record/291154/files/Abstracts_19_06_ 20_12_48_58_40_69_28_84_171_0.pdf (accessed 2 March 2020).
Insights from Port wine exports 
Peixoto, J.P. and Oort, A.H. (1992), Physics of Climate, AIP-Press, Boston.

Rebelo, J., Macedo, A. and Gouveia, S. (2020), "Export determinants of port wine. Three centuries later", in Duarte, A., Simões, M., Bação, P. and Martins, R. (Eds), Estudos de Homenagem a João Sousa Andrade, pp. 359-374, Almedina.

Santeramo, F.G. and Lamonaca, E. (2019), "The effects of non-tariff measures on agri-food trade: a review and meta-analysis of empirical evidence", Journal of Agricultural Economics, Vol. 70 No. 3, pp. 595-617.

Santeramo, F.G., Lamonaca, E., Nardone, G. and Seccia, A. (2019), "The benefits of country-specific non-tariff measures in world wine trade", Wine Economics and Policy, Vol. 8 No. 1, pp. 28-37.

Santos, J.A., Grätsch, S.D., Karremann, M.K., Jones, G.V. and Pinto, J.G. (2013), "Ensemble projections for wine production in the Douro Valley of Portugal", Climatic Change, Vol. 117, pp. 211-225.

Santos, M., Fonseca, A., Fraga, H., Jones, G.V. and Santos, J.A. (2020), "Bioclimatic conditions of the Portuguese wine denominations of origin under changing climates", International Journal of Climatology, Vol. 40 No. 2, pp. 927-941.

Shapiro, J.S. (2016), "Trade costs, $\mathrm{CO}_{2}$, and the environment", American Economic Journal: Economic Policy, Vol. 8 No. 4, pp. 220-254.

Silva, J.M.C.S. and Tenreyro, S. (2006), “The log of gravity”, Review of Economics and Statistics, Vol. 88 No. 4, pp. 641-658.

Štulec, I., Petljak, K. and Naletina, D. (2019), "Weather impact on retail sales: how can weather derivatives help with adverse weather deviations?", Journal of Retailing and Consumer Services, Vol. 49, pp. 1-10.

The Economist (2019) "The twilight of the WTO - the trading system's referee is about to leave the field", 28 November, available at: https:/www.economist.com/leaders/2019/11/28/the-tradingsystems-referee-is-about-to-leave-the-field (accessed: 2 March 2020).

Tinbergen, J. (1962), Shaping the World Economy: Suggestions for an International Economic Policy, Twentieth Century Fund, New York, NY.

UNCTAD (2019), International classification of non-tariff measures - 2019 edition, available at: https:// unctad.org/en/PublicationsLibrary/ditctab2019d5_en.pdf (accessed: 2 March 2020).

Wilkins, E., de Urioste-Stone, S., Weiskittel, A. and Gabe, T. (2018), "Weather sensitivity and climate change perceptions of tourists: a segmentation analysis", Tourism Geographies, Vol. 20 No. 2, pp. 273-289, Routledge.

Wilks, D.S. (2020), Statistical Methods in the Atmospheric Sciences, Elsevier, Amsterdam.

Yue, C., Beghin, J. and Jensen, H.H. (2006), "Tariff equivalent of technical barriers to trade with imperfect substitution and trade costs", American Journal of Agricultural Economics, Vol. 88 No. 4, pp. 947-960.

\section{Corresponding author}

Anthony Macedo can be contacted at: anthonym@utad.pt

For instructions on how to order reprints of this article, please visit our website:

www.emeraldgrouppublishing.com/licensing/reprints.htm

Or contact us for further details: permissions@emeraldinsight.com 